\title{
Long-Term Surveillance Plan For the Cheney Disposal Site Near Grand Junction, Colorado
}

July 1997

\author{
RECEIVED \\ SEP 291997 \\ QSTI
}

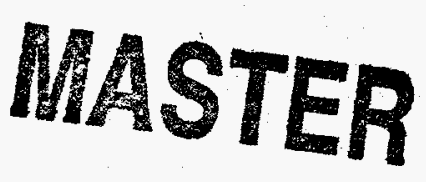

DISTRIBUTION OF THIS DOCUMENT IS UNLIMTTED 


\section{DISCLAMMIER}

Portions of this docament may be illegible in electronic image products. Images are produced from the best available original docoment. 
This report has been reproduced from the best available copy. Available in paper copy and microfiche

Number of pages in this report: 56

DOE and DOE contractors can obtain copies of this report from:

Office of Scientific and Technical Information

P.O. Box 62

Oak Ridge, TN 37831

(615) 576-8401

This report is publicly available from:

National Technical Information Service

Department of Commerce

5285 Port Royal Road

Springfield, VA 22161

(703) $487-4650$ 


\section{DISCLAIMER}

This report was prepared as an account of work sponsored by an agency of the United States Government. Neither the United States Government nor any agency thereof, nor any of their employees, makes any warranty, express or implied, or assumes any legal liability or responsibility for the accuracy, completeness, or usefulness of any information, apparatus, product, or process disclosed, or represents that its use would not infringe privately owned rights. Reference herein to any specific commercial product, process, or service by trade name, trademark, manufacturer, or otherwise does not necessarily constitute or imply its endorsement, recommendation, or favoring by the United States Government or any agency thereof. The views and opinions of authors expressed herein do not necessarily state or reflect those of the United States Government or any agency thereof. 
REV. 0

LONG-TERM SURVEILLANCE PLAN

FOR THE

CHENEY DISPOSAL SITE

NEAR GRAND JUNCTION, COLORADO

July 1997

Prepared for

U.S. Department of Energy

Environmental Restoration Division

UMTRA Project Team

Albuquerque, New Mexico

Prepared by

Jacobs Engineering Group Inc.

Albuquerque, New Mexico 


\section{PREFACE}

The Cheney disposal cell is scheduled to remain open until 2023 (or until the cell is filled to its design capacityl during the summer months to accept wastes from vicinity properties. Long-term surveillance and monitoring will be conducted on the completed portions of the cell. This preface addresses the unique issues of inspecting and monitoring a partiallyoperating cell. When the cell is closed, this information will no longer be valid. While the cell is operational, the following information applies:

- The cell-closure hole is located at what will be the crest of the topslope. The hole is approximately 1200 feet (ft) $(366$ meters [m]) by $750 \mathrm{ft}(230 \mathrm{~m})$ and varies in depth from about 10 to 30 feet $(3$ to $9 \mathrm{~m})$. The sides are sloped at 3 to 1 and a ramp provides access for placing incoming contaminated materials. Runoff from precipitation stays within the cell-closure hole. Eventually, the hole will be filled; closure is planned for $\mathbf{2 0 2 3}$ or when the cell is filled to design capacity. Transition material will be added to spaces not filled by contaminated materials to bring the surface to the proper grade. Then the cover will be extended from the hole boundaries to complete the disposal cell.

- While the site is operational, the U.S. Department of Energy (DOE) will notify the disposal cell operating contractor of inspections and coordinate with the operating contractor while on the site.

- The open, operating pit at the site is excluded from long-term surveillance plan (LTSP) inspections. However, observed operations that could influence the performance of the closed portions of the disposal cell should be considered and noted during the inspection. For example, a lined settling pond at the site is used to decontaminate vicinity property trucks leaving the site. Draining the pond and water loss by evaporation or leakage could result in air-borne dispersion of the radiologicallycontaminated pond sediments on and off the site.

- Site inspections will cover the completed portions of the disposal cell, the surrounding disposal site area, and the immediate off-site areas.

- Off-site DOE monitor wells will be inspected until they are properly decommissioned.

- Site inspections will be conducted in accordance with a DOE-approved safety and health plan. While the site is operational, inspectors will comply with operating contractor health and safety requirements including site sign-in, industrial hygiene monitoring, traffic patterns, and personal protective equipment.

Some details in this document will be not be available until after cell closure. These include number of survey markers, boundary markers, and plates 1 and 2 (as-built drawings). 


\section{TABLE OF CONTENTS}

\section{Section}

Page

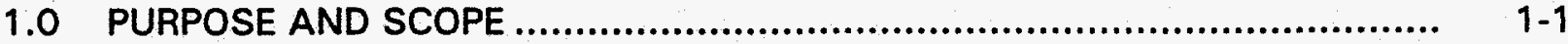

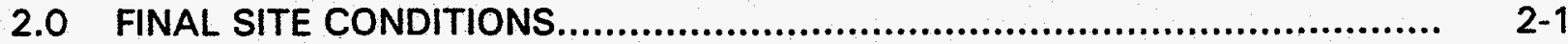

2.1 Site history .......................................................................... $2-1$

2.2 General description of the site vicinity ......................................... $2-2$

2.3 Disposal site description............................................................ $2-4$

2.3.1 Site ownership and legal description.................................. 2-4

2.3.2 Directions to the disposal site ........................................... $2-4$

2.3.3 Description of surface conditions ..................................... $2-4$

2.3.4 Permanent site-surveillance features................................... $\quad 2-5$

2.4 Disposal cell design .............................................................. $2-7$

2.5 Ground water characterization ................................................. $2-8$

2.5.1 Hydrogeologic setting ................................................... $2-8$

2.5.2 Background ground water quality .................................... 2-9

2.6 Ground water protection ................................................... $2-10$

2.7 Volunteer plant growth........................................................... $2-11$

2.7.1 Plant species and density ............................................ $2-11$

2.7.2 Rooting patterns..................................................... $2-13$

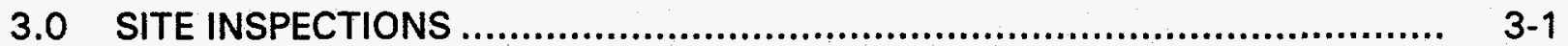

3.1 Inspection frequency........................................................... 3-1

3.2 Inspection team................................................................... $3-1$

3.3 Annual inspections .......................................................... $3-1$

3.4 Follow-up inspections......................................................... $3-3$

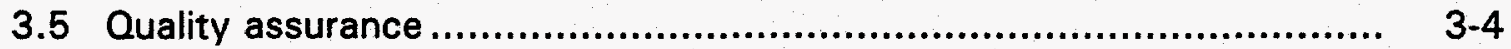

4.0 CUSTODIAL MAINTENANCE AND REPAIR........................................ $4-1$

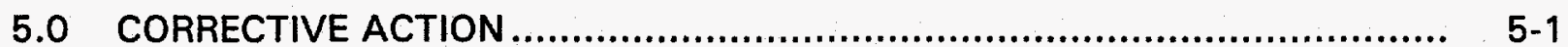

5.1 Site-specific issues ............................................................. $5-1$

5.2 Corrective action ........................................................... $5-1$

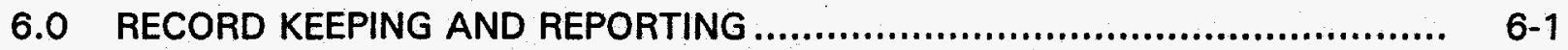

6.1 Permanent site file ............................................................... $6-1$

6.2 Inspection reports/annual reports........................................... $6-1$

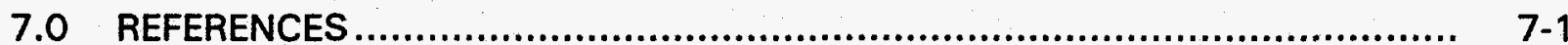

$\begin{array}{ll}\text { ATTACHMENT } 1 & \text { NRC CONCURRENCE AND LICENSING DOCUMENTATION } \\ \text { ATTACHMENT } 2 & \text { SITE REAL ESTATE INFORMATION } \\ \text { ATTACHMENT } 3 & \text { EMERGENCY NOTIFICATION LETTERS }\end{array}$




\section{LIST OF FIGURES}

Figure

Page

2.1 Cheney disposal site, Mesa County, Colorado

2.2 Locations of plant densities, vegetation transects, and plant

excavations, Cheney disposal cell, Grand Junction, Colorado

3.1 Steps for follow-up inspections, custodial maintenance, and corrective action, Grand Junction, Colorado, disposal site

\section{LIST OF PLATES}

Plate

$1 \quad$ (In preparation)

\section{LIST OF TABLES}

Table

Page

2.1 (To be developed)

2.2 Estimated number of plants on the Cheney disposal cell near Grand Junction, Colorado. 2-14 


\section{LIST OF ACRONYMS}

Acronym

BLM

DOE

EPA

LTSP

$\mathrm{MCL}$

NGVD

NRC

POC

QA

RAP

TDS

UMTRA

UMTRCA

\section{Definition}

Bureau of Land Management

U.S. Department of Energy

U.S. Environmental Protection Agency

long-term surveillance plan

maximum concentration limit

National Geodetic Vertical Datum

U.S. Nuclear Regulatory Commission

point of compliance

quality assurance

remedial action plan

total dissolved solids

Uranium Mill Tailings Remedial Action

Uranium Mill Tailings Radiation Control Act 


\section{CHANGE HISTORY}

\begin{tabular}{c|c|l}
\hline Document version & \multicolumn{1}{|c}{ Date } & \multicolumn{1}{c}{ Pages/comments } \\
\hline Rev. 0, Ver. 0 & $4-97$ & $\begin{array}{l}\text { Initial version prepared for DOE } \\
\text { review. }\end{array}$ \\
\hline
\end{tabular}




\subsection{PURPOSE AND SCOPE}

This long-term surveillance plan (LTSP) describes the U.S. Department of Energy's (DOE) long-term care program for the Uranium Mill Tailings Remedial Action (UMTRA) Project Cheney disposal site. The site is in Mesa County near Grand Junction, Colorado.

The U.S. Nuclear Regulatory Commission (NRC) developed regulations for the issuance of a general license for the custody and long-term care of UMTRA Project disposal sites in 10 CFR Part 40. The purpose of this general license is to ensure that the UMTRA Project disposal sites are cared for in a manner that protects public health and safety and the environment. Before each disposal site is licensed, the NRC requires the DOE to submit a site-specific LTSP. The DOE prepared this LTSP to meet this requirement for the Cheney disposal site. The general license becomes effective when the NRC concurs with the DOE's determination that remedial action is complete at the Cheney cell and the NRC formally accepts this LTSP. Attachment 1 contains the concurrence letter from the NRC.

This document describes the long-term surveillance program the DOE will implement to ensure that the Cheney disposal site performs as designed. The program is based on site inspections to identify potential threats to disposal cell integrity. The LTSP is based on the UMTRA Project long-term surveillance program guidance (DOE, 1996a) and meets the requirements of $10 \mathrm{CFR} \S 40.27(\mathrm{~b})$ and $40 \mathrm{CFR} \S 192.03$. 


\subsection{FINAL SITE CONDITIONS}

Remedial action at the former uranium processing site in Grand Junction, Colorado, and the cleanup of vicinity properties in and around Grand Junction consisted of excavating and relocating residual radioactive materials to the Cheney disposal site. The DOE constructed a disposal cell to control the residual radioactive material in accordance with 40 CFR Part 192. The site completion report is being prepared in three phases and contains a detailed description of final site conditions. Phase I of the completion report began in 1994. Phase II reflects activities from 1994 to 1998 . Phase III will take the project to completion.

\subsection{SITE HISTORY}

The Cheney disposal site was constructed to stabilize waste from a uranium processing site in Grand Junction, Colorado.

The Climax Uranium Company opened a mill in Grand Junction in 1951. It was designed and built for uranium production, with by-product vanadium production. A solvent-extraction circuit was added in 1956. The mill process included ore neutralization, sand/slime separation, and treatments for sand and slime. An acid-leaching and solvent extraction process recovered uranium from the sand. The slimes were salt-roasted, then water-leached to remove vanadium, and finally acid-leached with a solvent-extraction step to extract uranium and the remaining vanadium.

In 1960, the Climax Uranium Company was incorporated into American Metals Climax, Inc., which operated the mill until February 1970. Approximately 4.6 million dry tons of tailings were produced. Climax released approximately 500,000 cubic yards $\left(\mathrm{yd}^{3}\right)\left(400,000\right.$ cubic meters $\left.\left[\mathrm{m}^{3}\right]\right)$ of tailings to private individuals and contractors for use as construction fill material from 1951 to 1966.

The mill was dismantled and the tailings pile was stabilized in place from late 1970 to early 1971. Contaminated materials remediated from vicinity properties in the Grand Junction area were stored in the evaporation ponds east of the tailings pile.

In 1989, Phase I of the UMTRA Project remedial action, which included fencing around the processing site, constructing water retention ponds, and constructing the wastewater treatment plant foundation, was completed. Phase II construction began in 1990; it included constructing the disposal cell and assembling the wastewater treatment plant. Tailings relocation to the Cheney disposal cell started in the spring of 1991. Remedial action at the Grand Junction processing site was completed in 1994. 
At the Cheney disposal site, the residual radioactive materials were placed in a single disposal cell. Residual radioactive materials from remediation of vicinity properties were also relocated to the Cheney disposal site.

The completion report documents compliance with the remedial action plan (RAP) and the site as-built conditions (DOE, 1997). In addition, the DOE will prepare a final audit report and certification summary and submit it, along with the completion report, to the NRC for concurrence. Concurrence from the NRC on the completion report will be included in the permanent site file.

\subsection{GENERAL DESCRIPTION OF THE SITE VICINITY}

The Cheney disposal site is in Mesa County in southwest Colorado on the western slope of the Rocky Mountains. The site is approximately 18 miles (mi) (29 kilometers [km]) south of the town of Grand Junction, Colorado in Township 3 South, Range 2 East, Sections 11 and 12 (Figure 2.1). The site vicinity is briefly described below. The site environmental impact statement (DOE, 1986) and the RAP (DOE, 1991a) contain detailed descriptions.

The general climatic regime in the vicinity of the Cheney disposal site is semiarid. Summer days with maximum temperatures near $90^{\circ}$ Fahrenheit (F) $\left(32^{\circ}\right.$ Centigrade $\left.[\mathrm{C}]\right)$ and minimum temperatures near $60^{\circ} \mathrm{F}\left(16^{\circ} \mathrm{C}\right)$ are common. Monthly average temperatures range from $26.6^{\circ} \mathrm{F}\left(-3.0^{\circ} \mathrm{C}\right)$ in January to $78.7^{\circ} \mathrm{F}$ $\left(26^{\circ} \mathrm{C}\right)$ in July. Summer rains occur mainly as scattered intense showers from thunderstorms that develop over the nearby mountains. Winter snows are fairly frequent; however, they are mostly light and the snow melts quickly. Grand Junction's average annual precipitation is 8.4 inches (21 centimeters [cm]). Snowfall at Grand Junction averages 24 inches $(69 \mathrm{~cm})$.

The Cheney site is located on a pediment surface that forms a drainage divide between two small ephemeral washes. The drainage divide slopes gently southwest at approximately 2 percent. The site elevation ranges from about 5190 to 5270 feet (ft) (1580 to 1600 meters [m]) above mean sea level. The two washes merge with Indian Creek, approximately two-thirds of a mile below the site. Indian Creek flows into Kannah Creek 4 to $5 \mathrm{mi}(6$ to $8 \mathrm{~km})$ below the confluence of the ephemeral washes. Kannah Creek empties in the Gunnison River $2 \mathrm{mi}(3 \mathrm{~km})$ beyond its confluence with Indian Creek.

An area of 240 acres (ac) (97 hectares [ha]) drains toward the Cheney disposal site. Slopes in the watershed average 3 percent. The maximum flow length is approximately $9500 \mathrm{ft}(2900 \mathrm{~m})$. Sheetwash and rill erosion are the primary erosive forces currently active at the site. Minor gullying occurs in the small ephemeral washes. A small upland watershed east of the site and a deeply incised surface gully south of the site are the only significant surface water and geomorphic features. A drainage swale diverts water from the disposal cell watershed. Water that falls on top of the cell drains to aprons and to the ground around the cell. 


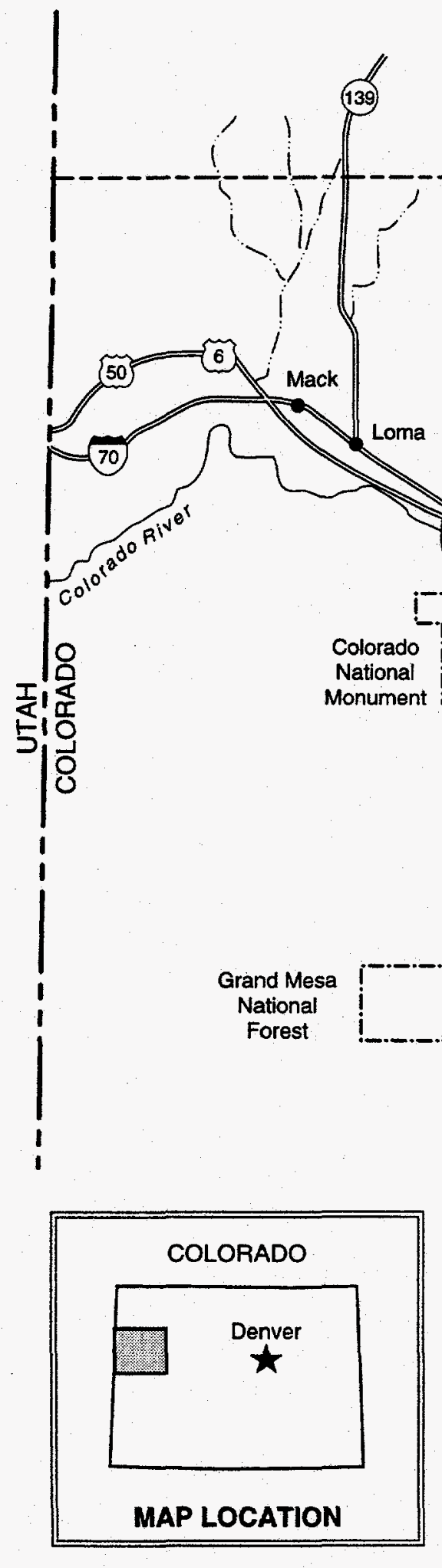

Garfield Co.

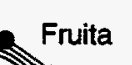

Fruita GRAND JUNCTION

South Shale Ridge

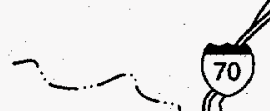

70
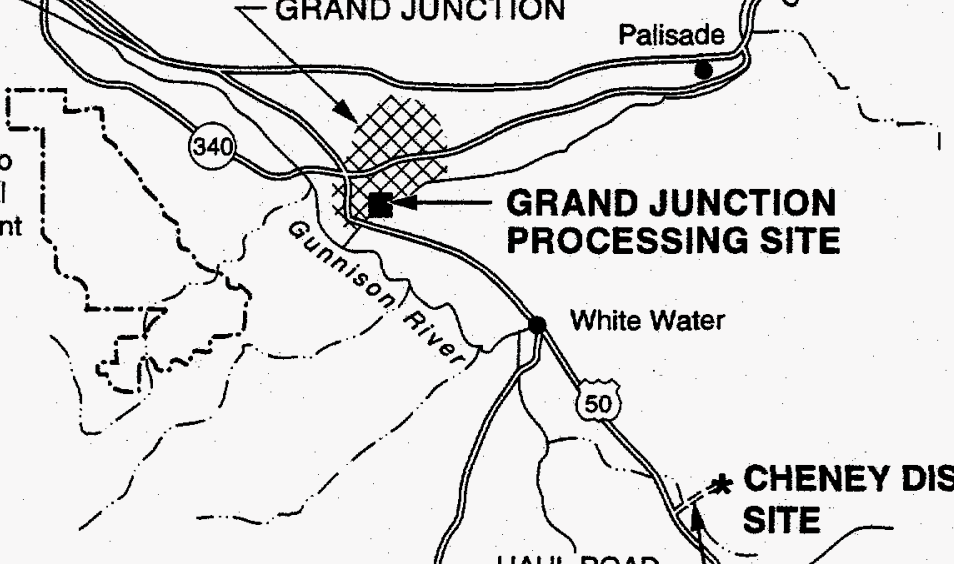

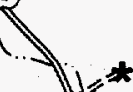

CHENEY DISPOSAL
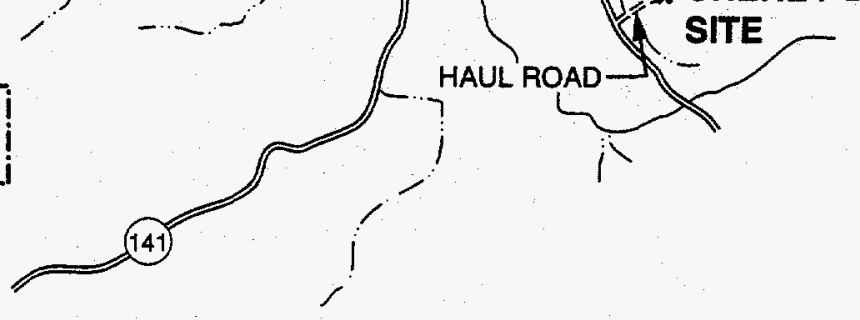

\section{LEGEND \\ (70) INTERSTATE HIGHWAY \\ 50 U.S. HIGHWAY \\ (141) STATE HIGHWAY \\ -.... EPHEMERAL STREAM}

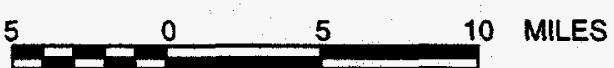

FIGURE 2.1

CHENEY DISPOSAL SITE MESA COUNTY, COLORADO 


\subsection{DISPOSAL SITE DESCRIPTION}

This section briefly describes the disposal site; detailed descriptions can be found in the site RAP (DOE, 1991 a) and completion report (DOE, 1997).

\subsubsection{Site ownership and legal description}

The United States government currently owns the Cheney disposal site and most of the surrounding area. The Bureau of Land Management (BLM) permanently transferred administration of public land to the DOE in February 1990 for use as the Cheney disposal site. The BLM administers the adjacent surrounding lands. Attachment 2 gives a legal description of the disposal site. Plate 1 shows the final site boundary and identifies ownership of the site and surrounding areas at the time of licensing.

\subsubsection{Directions to the disposal site}

Following the directions below, the Cheney disposal site can be reached by automobile via paved roads (Figure 2.1).

1. From Grand Junction, Colorado, take U.S. Highway 50 South.

2. Follow Highway 50 past the junction of State Highway 141. Approximately $7 \mathrm{mi}(12 \mathrm{~km})$ past this junction, turn left onto the access road.

3. Follow the access road approximately $1.5 \mathrm{mi}(2.5 \mathrm{~km})$ to the locked gate.

Entry to the disposal site is restricted by a fence at the site entrance. The south access gate is locked; the key needed to enter the site may be obtained at the Grand Junction Office.

\subsubsection{Description of surface conditions}

The Cheney disposal cell covers approximately 60 ac (24 ha) within the 360 ac $(146 \mathrm{ha})$ of land set aside for the site. The completion report contains a detailed description of site conditions, including the results of the site topographic survey (Plate 1).

During final site grading, all areas were contoured to promote drainage away from the disposal cell. A mix of grasses and sagebrush was used to revegetate all disturbed areas of the disposal site not covered by riprap (DOE, $1991 \mathrm{~b}$ ).

At the completion of remedial action, the DOE documented final disposal site conditions with site maps, as-built drawings, and ground and aerial photographs. 
2.3.4 Permanent site-surveillance fe ty

Survey and boundary monuments, site markers, and warning signs are the permanent long-term surveillance features of the Cheney disposal site. Plate 1 shows the locations of these features and Table 2.1 provides survey grid coordinates. Typical construction and installation specifications for these features are shown in the long-term surveillance guidance (DOE, 1996a) and subcontract (DOE, 1991b) documents.

(Number) survey monuments establish permanent horizontal control based on the Colorado State Plane Coordinate System (Central Zone) and are referenced to the Project Survey Control Points. Plate 1 shows these control points and Table 2.1 gives their location coordinates. The permanent survey monuments (SM-x) are Berntsen RT-1 markers set in concrete, with the monument about 4 inches $(10 \mathrm{~cm})$ above ground level. Magnets in the markers permit easier detection if the markers become buried over time. The survey monument identification number is stamped on the top of the metal cap.

(Number) site boundary corners define the final site boundary. Of these, (number) are marked with boundary monuments. The boundary monuments are Berntsen A-1 markers set in concrete. Of these, standard boundary monuments are used at (number) locations. The standard monuments are reinforced concrete that extend to a depth of $6 \mathrm{ft}(1.8 \mathrm{~m})$ or to hard rock. The marker extends about 1 inch ( 2.5 centimeters $[\mathrm{cm}]$ ) above the ground surface. The remaining (number) monuments have been modified for area conditions and are concrete, placed to a minimum depth of $3 \mathrm{ft}(1 \mathrm{~m})$ or 6 inches $(15 \mathrm{~cm})$ below rock. In these, the marker extends a minimum of 12 inches $(0.3 \mathrm{~m})$ above ground surface. Magnets in the A-1 monuments allow easier detection if they become buried. The boundary monument identification number is stamped on the top of the metal cap.

Two unpolished granite markers with an incised message identify the Cheney disposal site. The message includes a drawing showing the general location of the stabilized disposal cell within the site boundaries, the date of closure, the weight of the tailings, and the amount of radioactivity (in Curies). Site marker SMK-1 near the west site access gate is set in reinforced concrete extending 6 $\mathrm{ft}(1.8 \mathrm{~m})$ below the ground surface. Site marker SMK-2 is set in reinforced concrete extending to the top of the frost protection barrier.

The DOE posted 18 -inch $(946-\mathrm{cm})$ by 24 -inch $(61-\mathrm{cm})$ property-use warning signs around the disposal site perimeter at approximately $200-\mathrm{ft}(60-\mathrm{m})$ intervals. The site entrance sign is at the south access gate near site marker SMK-1 (location to be confirmed). The entrance sign displays the DOE 24-hour telephone number for calls concerning the site. In addition to the entrance sign, (number) perimeter warning signs are located about $5 \mathrm{ft}(1.5 \mathrm{~m})$ inside the site 
Table 2.1

(To be developed) 
fence. The warning signs on the southern end of the site are attached to the fence. The other warning signs are mounted on steel posts with the tops of the signs about $6 \mathrm{ft}(1.8 \mathrm{~m})$ above the ground surface (locations to be confirmed). The sign posts are embedded in concrete to a depth of about $3 \mathrm{ft}(1 \mathrm{~m})$ below the ground surface.

\subsection{DISPOSAL CELL DESIGN}

The 60-ac (24-ha) disposal cell is located on a pediment surface that forms a drainage divide between two small ephemeral washes. The area of the disposal cell is not subject to significant hazard from slope failure processes such as landslides, debris flows, mud flows, and rock falls. The geomorphic processes posing a potential hazard to the stabilized disposal cell are ephemeral drainage channel changes, low-gradient slope erosion, and wind erosion; however, these processes are not reasonably expected to affect the disposal cell within the next 1000 years, or within 200 years at a minimum.

The disposal cell is constructed partially below grade and rises above the surrounding terrain to a maximum elevation of about $5260 \mathrm{ft}(1603 \mathrm{~m})$ above National Geodetic Vertical Datum (NGVD) at the top of the 2.3 percent slope. The disposal cell contains $4,031,402 \mathrm{yd}^{3}\left(3,082,410 \mathrm{~m}^{3}\right)$ of relocated tailings and other residual radioactive materials, primarily contaminated soils and demolition debris. A cell-closure hole was incorporated into the tailings embankment to allow approximately $500,000 \mathrm{yd}^{3}\left(382,300 \mathrm{~m}^{3}\right)$ of additional contaminated material from vicinity properties to be placed in the tailings embankment. Clean fill dikes contain the above grade portion of the cell. The dikes are sloped at 20 percent. The top of the cell slopes 2.1 to 2.3 percent.

The top of the disposal cell is capped with a multiple-component cover. A 1.5$\mathrm{ft}(0.45-\mathrm{m})$-thick transition layer of off-pile materials was placed on top of the contaminated materials. A 2-ft (0.6-m)-thick radon/infiltration barrier was placed over the transition materials. This barrier is constructed of selected onsite materials obtained from the embankment foundation excavation. It is designed to reduce the radon-222 flux from the disposal cell to less than 20 picocuries per square meter per second and minimize water infiltration into the tailings. A 2-ft $(0.6 \mathrm{~m})$ frost-protection layer was placed over the radon barrier to prevent the adverse effects of freeze-thaw cycles. A $0.5-\mathrm{ft}(0.15-\mathrm{m})$-thick, coarse-grained bedding layer on top of the radon/infiltration barrier provides a capillary break, promotes drainage of infiltrating water away from the radon barrier, and prevents damage from the erosion-protection layer. This layer also extends over the clean fill dike sideslopes. The topslopes and sideslopes of the disposal cell are capped with riprap to protect against wind and water erosion and prevent damage to the underlying frost-protection and radon/infiltration barrier layers.

The erosion-protection layer is $1 \mathrm{ft}(0.3 \mathrm{~m})$ thick. Maximum grade is 2.3 percent on the topslopes and 20 percent on the sideslopes. These grades, in conjunction with the bedding layer, divert excess surface water runoff from the 
disposal cell and convey it to adjacent site grades, thereby minimizing the risk of significant erosion. Both the topslope and sideslope covers are designed to minimize the potential for deep percolation of precipitation into the residual radioactive material.

At the toe of the disposal cell a riprap apron and toe ditch carry water away from the cell and provide erosion protection from gullying. A rock-lined interceptor ditch abuts the upslope portion of the disposal cell to divert surface flow away from the cell (DOE, 1997).

The site completion report contains detailed engineering drawings of the disposal cell (DOE, 1997).

\subsection{GROUND WATER CHARACTERIZATION}

The DOE has characterized the hydrogeologic units, aquifer hydraulic and transport properties, and geochemical conditions at the Cheney disposal site. This information is summarized below, with details provided in Attachments 3 and 4 of the RAP (DOE, 1991a) and the environmental impact statement (DOE, 1986).

\subsubsection{Hydrogeologic setting}

The disposal site area is on a broad, moderately sloping surface on the west flank of Grand Mesa, east of the Gunnison River. The surface consists of alluvium, colluvium, and terrace gravels underlain by a thick sequence (greater than $8000 \mathrm{ft}$ [ $2438 \mathrm{~m}$ ]) of sedimentary rock. The disposal site is underlain by 5 to $40 \mathrm{ft}(1.5$ to $131 \mathrm{~m})$ of alluvium. Beneath the alluvium is approximately 700 $\mathrm{ft}(213 \mathrm{~m})$ of Mancos Shale, which overlies the Dakota Sandstone.

Ground water in the disposal site area occurs transiently in thin paleochannels within the lower portion of the alluvium, in fracture systems in the underlying Mancos Shale; and permanently in the Dakota Sandstone. Detailed field investigations, including geophysical surveys and test pits, identified a large area suitable for the disposal cell that was devoid of paleochannels containing saturation zones. The Dakota Sandstone is defined as the uppermost aquifer beneath the Cheney disposal site.

Alluvial paleochannels exposed by continuous trenches contain saturation zones ranging from less than 1 to more than $6 \mathrm{ft}(1.8 \mathrm{~m})$ thick. Paleochannels are separated in some cases by relatively large distances (greater than $500 \mathrm{ft}[152$ m]). Three separate paleochannel flow systems have been identified in the disposal site vicinity. One system passes within approximately $100 \mathrm{ft}[30 \mathrm{~m}]$ of the northwest corner of the disposal cell footprint and was relocated outside the footprint. The other two are within approximately $600 \mathrm{ft}[183 \mathrm{~m}]$ of the southern portion of the footprint. 
Ground water in the Mancos Shale is found in discontinuous zones separated both laterally and vertically by large regions of unsaturated rock. Aquifer pumping tests and computer simulations demonstrate that the Mancos Shale yields less than 150 gallons $(568 \mathrm{~L})$ per day and is considered "limited use" (DOE, 1991a). Pockets of ground water were found in isolated intervals in the unweathered Mancos Shale at several depths, but principally between 50 and $120 \mathrm{ft}(15$ and $37 \mathrm{~m})$ and between 275 and $492 \mathrm{ft}(84$ and $150 \mathrm{~m})$. The ground water occurs in saturated, multiple fracture zones. Core water saturation measurements indicate the Mancos Shale matrix is unsaturated even in zones adjacent to water-filled fractures.

Three monitor wells completed in the Dakota Sandstone encountered confined ground water, with hydraulic pressures greater than $360 \mathrm{ft}(110 \mathrm{~m})$ above the Mancos Shale/Dakota Sandstone contact. Ground water in the Dakota Sandstone is confined by unsaturated low-permeability shales and sandstone. Total dissolved solids (TDS) concentrations exceed 10,000 milligrams per liter $(\mathrm{mg} / \mathrm{L})$, and thus ground water in the Dakota Sandstone (uppermost aquifer) is considered "limited use" (DOE, 1991a).

Age dating, hydraulic testing, and chemical analyses show very little, if any, hydraulic connection between the alluvium, Mancos Shale, and Dakota Sandstone. Comparison of the ages of paleochannel ground water with the ages of shallow Mancos Shale and Dakota Sandstone ground water indicates no direct interconnection. Carbon-14 analyses of ground water samples collected from the three units show that alluvial ground water is relatively young (less than 2000 years), the shallow Mancos Shale ground water is old $(20,000$ to 30,000 years), and the Dakota Sandstone ground water is very old (probably more than 42,000 years).

\subsubsection{Background ground water quality}

Background ground water quality beneath the Cheney disposal site was determined prior to emplacement of tailings material in the disposal cell. Ground water quality data are presented in Attachment 3 of the RAP (DOE, 1991a). In general, ground water quality is good in the alluvium, poor in the Mancos Shale, and unusable even for stock watering in the Dakota Sandstone. Water quality in these units correlates well with the ages of the ground water, as noted above. The large differences in the chemical conditions of the ground water also suggest little if any hydraulic interconnection between the ground water zones.

Background ground water quality in the alluvium is fresh to slightly brackish, with TDS concentrations ranging from 640 to $1690 \mathrm{mg} / \mathrm{L}$. No concentrations of constituents listed in the U.S. Environmental Protection Agency (EPA) ground water protection standards (except selenium) exceed maximum concentration limits (MCL) (DOE, 1991a). Average sulfate and TDS concentrations exceed the EPA National Secondary Drinking Water Standards (40 CFR Part 143) of 250 and $500 \mathrm{mg} / \mathrm{L}$, respectively, by factors of less than 2 . Ground water in the alluvium is a mixed cation-sulfate type. Background ground water quality in the 
Mancos Shale is brackish, with elevated TDS levels ranging from 870 to 7010 $\mathrm{mg} / \mathrm{L}$. Average selenium concentrations slightly exceed the EPA MCL of 0.01 $\mathrm{mg} / \mathrm{L}$. Background ground water quality in the Dakota Sandstone is saline, with TDS concentrations exceeding $10,000 \mathrm{mg} / \mathrm{L}$. Ground water in this unit is thus considered "limited use," and the aquifer is neither a current nor a potential source of drinking water. In addition, ground water from this unit contains natural gas, and average concentrations of radium-226 and -228 exceed the EPA MCL of 5 picocuries per liter $(\mathrm{pCi} / \mathrm{L})$. Ground water in the Dakota Sandstone at the Cheney disposal site is a sodium-bicarbonate type.

The geochemical environment at the Cheney disposal site is favorable for attenuation of the hazardous constituents present in the Grand Junction tailings pore water. Attenuation data show that alluvial materials are likely to remove concentrations of most hazardous constituents in the tailings pore water to below their regulated concentration limits or laboratory method detection limits. The geochemical condition of the ground water in the Mancos Shale, where it is present below the disposal site, is highly reducing, and it is anticipated that many hazardous constituents (including cadmium, lead, molybdenum, selenium, and uranium) will be removed from the ground water by chemical precipitation. Geochemical modeling shows that these constituents are insoluble in the ground water in the Mancos Shale (DOE, 1991a).

\subsection{GROUND WATER PROTECTION}

To achieve compliance with the EPA ground water protection standards, the DOE's narrative supplemental standard ensures sufficient protection of human health and the environment (40 CFR Part 192). The supplemental standard applies to the uppermost aquifer (Dakota Sandstone) and does not include numerical concentration limits for the hazardous constituents identified in the contaminated materials at the Grand Junction processing site and vicinity properties. The basis of the supplemental standard is the "limited use" designation of the ground water in the Dakota Sandstone because the TDS content is greater than $10,000 \mathrm{mg} / \mathrm{L}$ and the ground water is not considered a current or potential source of drinking water (40 CFR $\$ 192.11(\mathrm{e})$ ). Furthermore, the uppermost aquifer lies approximately $750 \mathrm{ft}(229 \mathrm{~m})$ below the existing ground surface and is hydrogeologically isolated from surface recharge by confining sandstones and shales overlying the aquifer.

The DOE assessed the performance of the disposal cell in conjunction with the hydrogeologic system. The assessment shows the disposal cell will minimize and control releases of hazardous constituents to ground water and surface water and of radon emanation to the atmosphere, to the extent required to protect human health and the environment (DOE, 1991a). Natural, stable materials were used in constructing the Cheney disposal cell, thereby ensuring long-term performance. The DOE also demonstrated that design features necessary for compliance with the EPA ground water protection standards minimize the need for further disposal cell maintenance. 
Ground water will not be monitored at the Cheney disposal site. Based on an evaluation of site characterization data, a program to monitor ground water to demonstrate disposal cell performance has been determined inappropriate because ground water in the uppermost aquifer is of limited use, and a narrative supplemental standard has been applied to the site that does not include numerical concentration limits or a point of compliance (POC) (40 CFR $\$ 192.21(\mathrm{~g}))$. The basis for the limited use designation is the fact that ground water in the uppermost aquifer is neither a current nor a potential source of drinking water because the TDS content exceeds $10,000 \mathrm{mg} / \mathrm{L}$ ( $40 \mathrm{CFR}$ $\$ 192.11(\mathrm{e}))$. Also, the ground water in the uppermost aquifer at the Cheney disposal site is hydrogeologically isolated from the tailings material. Defining concentration limits and a POC would not further protect human health and the environment.

\subsection{VOLUNTEER PLANT GROWTH}

During the summer of 1995, a large number of volunteer plants were observed growing on the disposal cell. As a result of the subsequent study, monitoring volunteer plant growth will be one element of long-term surveillance monitoring at the Cheney disposal cell. UMTRA Project staff familiar with plant biointrusion on other UMTRA Project disposal cells visited the site on 19-20 September 1995, to assess plant growth on the cell (TAC, 1995).

\subsubsection{Plant species and density}

Numerous plant were observed growing on the topslope and eastern ( 2 percent) slope on the cell (Figure 2.2). No plants were observed on the steep sideslopes around the remainder of the cell. All plants observed were growing in soil that had been deposited among the rocks. Areas of the rock cover where the voids were not filled with dirt had no plants. The common plant species observed were summer cypress (Kochia sieversiana), Russian thistle (Solsola iberica), and halogeton (Halogeton glomertus). A few pigweed (Chenopodium sp.) and one shadscale (Atriplex confertifolia) were also observed. The dominant plant species are the same as those observed growing on the Shiprock, New Mexico, disposal cell except for halogeton, which was very rare on the Shiprock cell (DOE, 1992).

The plant growth on the topslope was mapped according to subjectively determined plant density using recent aerial photographs (Figure 2.2). Four plant density categories were identified: negligible, sparse, moderate, and dense. The number of plants within each category was estimated by tallying all plants in $6-\mathrm{ft}(2-\mathrm{m})$-wide belt transects of varying lengths. Four belt transects were sampled.

Plant growth was observed on approximately 46 ac (19 ha) of the 55-ac (22-ha) topslope. In this area, the few plants observed were negligible, typically 20 to $50 \mathrm{ft}(6$ to $15 \mathrm{~m})$ apart. Based on data from a $600-\mathrm{ft}(183-\mathrm{m})$-belt in transect $C$, the estimated density was 0.0028 plants per square foot $\left(\mathrm{ft}^{2}\right) 10.03$ per 


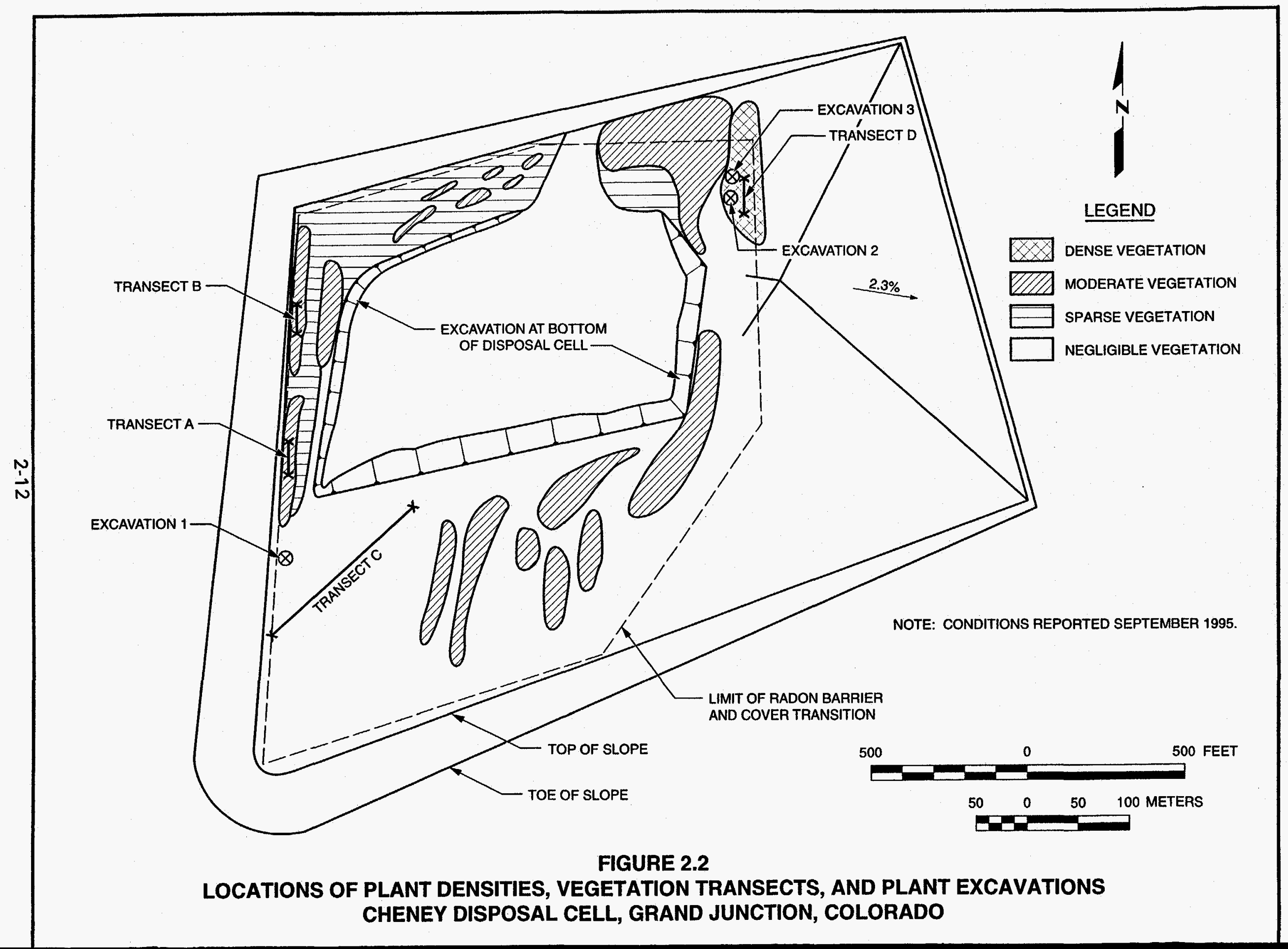


square meter $\left[\mathrm{m}^{2}\right.$ ]) (Table 2.2). Moderate plant growth covered an estimated 8.4 ac $(3.4 \mathrm{ha})$. Based on two $100-\mathrm{ft}(30-\mathrm{m})$ transects (transects $A$ \& B), the estimated plant density was 0.82 per $1 \mathrm{ft}^{2}\left(8.8\right.$ per $\left.1 \mathrm{~m}^{2}\right)$. Dense plant growth covered about 1 ac $(0.4 \mathrm{ha})$. Based on one $100-\mathrm{ft}(30-\mathrm{m})$ transect (transect D), the density was 1.02 plants per $1 \mathrm{ft}^{2}\left(11\right.$ per $\left.1 \mathrm{~m}^{2}\right)$. Based on these data, the 55-ac (22-ha) topslope of the Cheney disposal cell contained an estimated 345,600 plants in September 1995 (Table 2.2). Most of the mature plants growing on the topslope were 2 to $4 \mathrm{ft}(0.6$ to $1.2 \mathrm{~m})$ tall.

Twenty $9-\mathrm{ft}^{2}\left(0.8-\mathrm{m}^{2}\right)$ quadrants were sampled on the 2 percent eastern sideslope and the estimated number of plants on this 22-ac (9-ha) area was $4,000,000$. As with the topslope, summer cypress was the most common plant. Russian thistle and halogeton were much more common in this area than on the topslope. Plants in this area were shorter than on the topslope, typically being 6 to 18 inches $(15$ to $46 \mathrm{~cm})$ tall.

\subsubsection{Rooting patterns}

Plants were excavated in the sparse and dense plant growth areas to determine rooting patterns. Excavation number one was of a $4.5-\mathrm{ft}(1.4-\mathrm{m})$-tall summer cypress (Figure 2.2). Soil filled 12 inches $(20 \mathrm{~cm})$ of the 14-inch $(36-\mathrm{cm})$ rock layer. A tap root grew through the rock layer ending at the frost protection layer. Lateral roots grew out from the tap root into the rock/soil matrix. Some fine roots were growing into the frost protection layer, but the roots of this plant basically were restricted to the rock/soil matrix portion of the cover.

Excavation number two was in dense vegetation and included a $34-$ inch $(86-\mathrm{cm})$ -tall Russian thistle, a 32 -inch $(81-\mathrm{cm})$ tall summer cypress, and an 18 -inch (46$\mathrm{cm}$ )-tall halogeton (Figure 2.2). These plants did not display the branching rooting pattern observed in the summer cypress in the sparse plant density area. Instead, the tap roots went straight down. The halogeton tap root ended in the rock/soil matrix while the tap roots of the Russian thistle and summer cypress grew through the frost protection layer and up to 9 inches $(23 \mathrm{~cm})$ into the radon barrier. To verify the apparently shallow halogeton root system, a 17-inch (43-cm)-tall halogeton was excavated; the roots were confined mostly to the 13-inch $(33-\mathrm{cm})$ rock/soil matrix (excavation three).

Based on the limited number of excavations, it appears that the roots of plants growing in the areas of sparse plant density may be confined to the rock/soil matrix and the upper part of the frost-protection layer. Mature summer cypress and Russian thistle growing in the areas of moderate to dense plant growth likely have grown through the frost-protection layer and into the radon barrier. 
Table 2.2 Estimated number of plants on the Cheney disposal cell near Grand Junction, Colorado

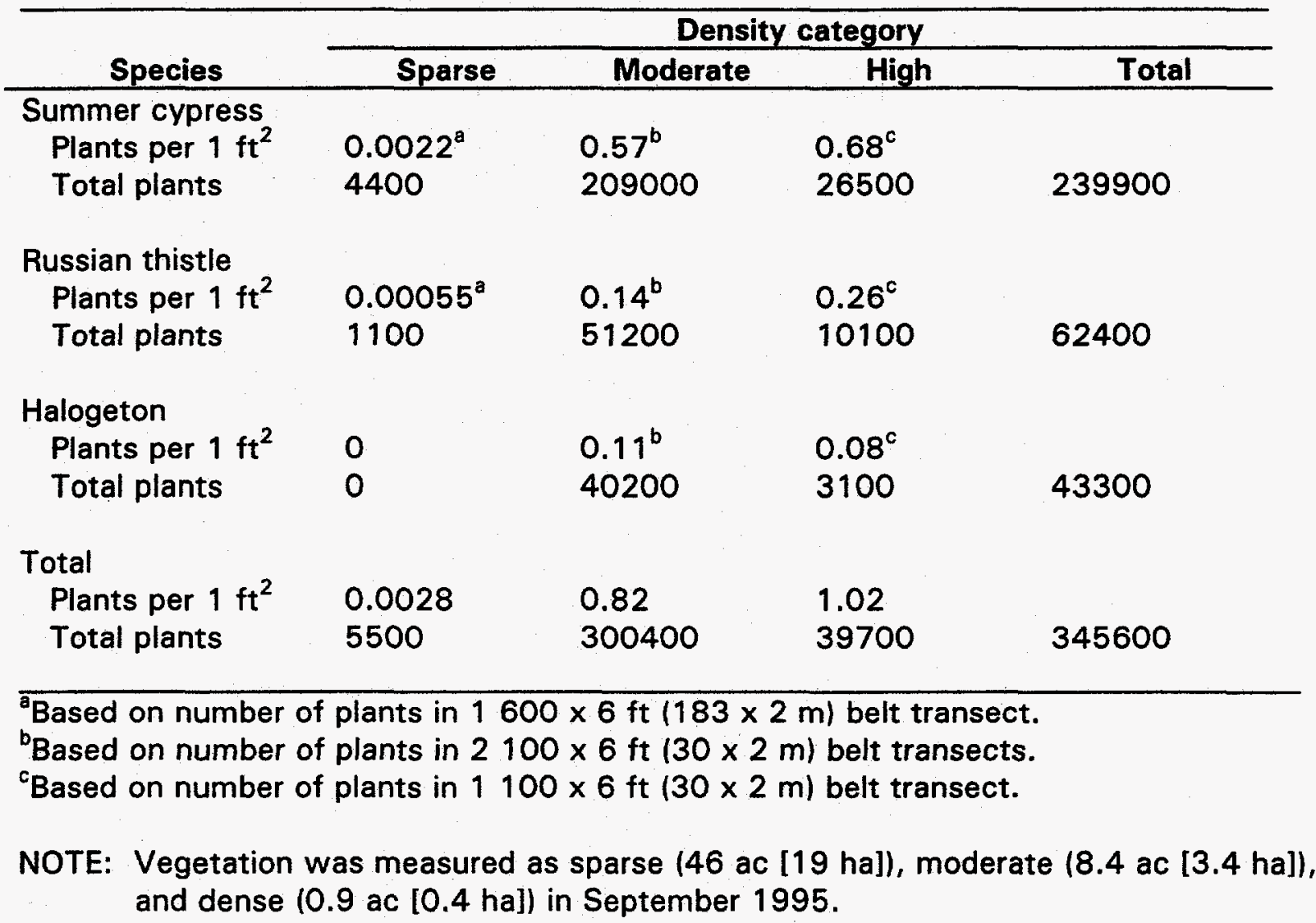




\subsection{SITE INSPECTIONS}

The DOE will inspect the Cheney disposal site to detect progressive change caused by slow-acting natural processes and to identify potential problems before the need for extensive maintenance, repairs, or corrective action. Inspections may also be conducted to follow-up on events or conditions that potentially could affect the disposal site. The DOE will compare the findings from these inspections to initial baseline conditions to identify changes over time and to provide a basis for future inspections, repairs, and corrective actions. Figure 3.1 shows this process. Section 5.0 describes custodial maintenance and repair. Section 5.0 discusses corrective action.

\section{$3.1 \quad$ INSPECTION FREQUENCY}

The DOE will inspect the Cheney disposal site annually. The DOE may schedule more frequent inspections if necessary. The DOE will notify the NRC of the inspection schedule.

\section{INSPECTION TEAM}

The inspection team will consist of a minimum of two inspectors who are qualified to inspect disposal cell integrity and to make preliminary assessments of modifying processes that could adversely affect the disposal cell.

If problems are observed that require more investigation, follow-up inspections will be performed and teams will include one or more technical specialists in appropriate disciplines.

\section{ANNUAL INSPECTIONS}

Inspectors will conduct a preinspection briefing before each inspection. The long-term surveillance program guidance document contains information useful in preparing for inspections (DOE, 1996a).

Site inspections will cover the disposal cell, the surrounding disposal site area, and the immediate off-site areas. Site inspections must be thorough enough to identify significant changes or active modifying processes that potentially could adversely impact the disposal cell. Surveillance will be performed to identify the unanticipated effects of modifying processes such as gully formation, slope erosion, changes to the rock cover, ephemeral drainage channel changes, and significant modifications by humans, animals, or plants. 


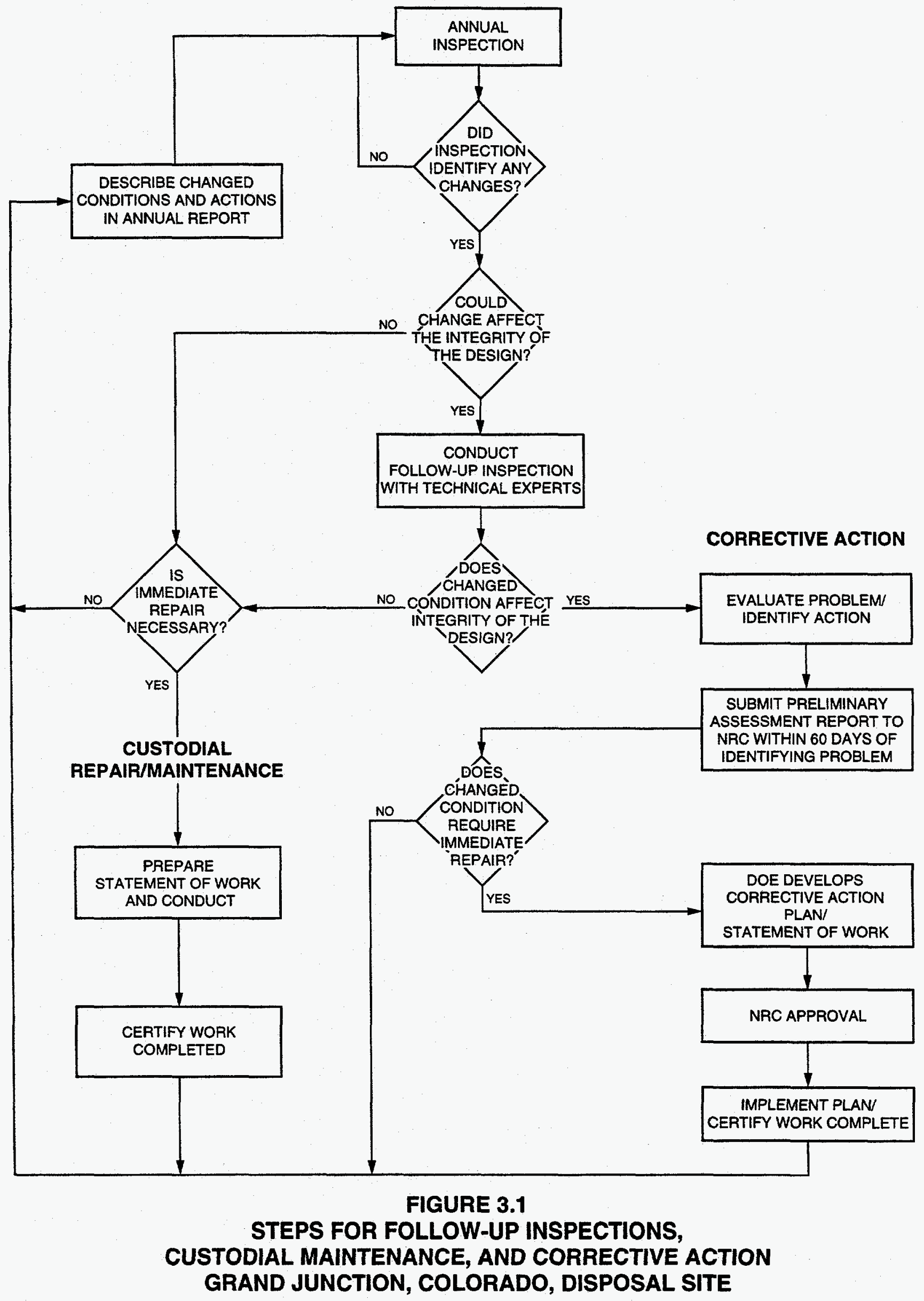


Inspectors will evaluate the integrity of the disposal cell by walking a series of transects around the perimeter and over the rock cover. Sufficient transects, at approximately $150-\mathrm{ft}(46-\mathrm{m})$ intervals, will be walked to ensure that the disposal cell is thoroughly covered and inspected. Diagonal transects of the topslopes will be made and the crest line will be walked. Additional transects will be walked along the sideslopes and rock apron. Transects along the entire length of the diversion ditch will be made to determine whether it is functioning as designed and can be expected to continue to function properly. Inspectors will make efforts to vary the transect paths from one inspection to the next to ensure small anomalies are not overlooked. The sample inspection checklist in the LTSP guidance document lists items that should be examined during inspections (DOE, 1996a).

The disposal cell has a rock cover and vegetation is not planned for the disposal cell. However, remedial action of the areas surrounding the disposal cell included revegetation. The area surrounding the disposal cell will be monitored to determine the success of the revegetation efforts. Inspectors also will inspect this area for evidence of erosion caused by wind, sheetwash, or changes in drainage patterns.

Site inspectors also will monitor damage to or disturbance of permanent sitesurveillance features, fencing, the gate, and locks.

From inside the disposal site, inspectors will visually survey the area approximately $0.25 \mathrm{mi}(0.40 \mathrm{~km})$ outside the disposal site boundary for evidence of land-use changes that indicate increased human activity such as land development or new roads and paths. Inspectors will note the condition of and changes to site access roads, surrounding vegetation, and relevant geomorphic features like gullies or ephemeral drainage channels. Potential impacts to the site will be noted. Off-site DOE monitor wells will be inspected until they are properly decommissioned.

\subsection{FOLLOW-UP INSPECTIONS}

In addition to annual inspections, DOE may conduct follow-up inspections due to unusual or annual inspection findings or observations. DOE also may conduct follow-up inspections to investigate and quantify specific problems found during a previous inspection or other DOE-initiated activity, or confirmed reports of vandalism (intrusion or damage), unusual occurrences, or other significant threat to the disposal site. The DOE will monitor the disposal cell area for the occurrence of extreme natural events (e.g., earthquakes, tornadoes, floods) and vandalism to ensure such events are investigated in a timely manner. To facilitate this, the DOE has requested notification from federal, state, and local agencies of discoveries or reports of purposeful intrusion or damage at the disposal site and in the disposal site area. Notification agreements with the Mesa County Sheriff's Office and the U.S. Geological Survey's National Earthquake Information Center are included in Attachment 3. The DOE will also monitor the weather for the occurrence of severe storms in the disposal cell 
vicinity. In addition, the DOE 24-hour telephone number is posted on the site entrance sign so the public can notify the DOE if problems are discovered. If an extreme natural event or vandalism has occurred, the DOE will inspect the cell to assess the damage. The notification, response, and follow-up activities will be documented. This documentation will be included in the annual site report to the NRC and become part of the permanent site file.

The nature of the occurrence and the amount of firsthand knowledge available will determine the DOE's response. If a situation poses a threat to the public, the DOE will notify individuals who may be affected and the appropriate federal, state, and local agencies, including the NRC. If necessary, the DOE will schedule a follow-up inspection to assess potential effects of the unusual occurrence, and will take necessary response action. Follow-up inspections also will be conducted to determine whether processes currently active at or near the site threaten site security or stability and to evaluate the need for custodial maintenance, repair, or other corrective action. The scope of these follow-up inspections may be broad and similar in nature to routine site inspections or focus on specific areas of concern.

\section{5 \\ QUALITY ASSURANCE}

The DOE has developed and implemented a quality assurance (QA) plan (DOE, $1996 \mathrm{~b})$ for the site inspection program that meets the requirements of DOE Order 5700.6C. Site inspections will be conducted in accordance with this QA plan. 


\subsection{CUSTODIAL MAINTENANCE AND REPAIR}

The DOE does not plan to conduct routine maintenance at the Cheney site. However, DOE will perform needed custodial maintenance or repair as determined from site inspections. Unscheduled custodial maintenance or repair may include the following:

- Repairing or replacing deteriorated or vandalized warning signs, fencing, gates, and locks.

- Removing deep-rooted plants determined to be a threat to the integrity of the cover.

- Reseeding areas surrounding the disposal cell.

After the work is completed and before contractors are released, DOE will verify that work was performed according to specification. The annual report to the NRC will document repairs that are performed. Copies of records, reports, and certifications will be included in the permanent site file. 


\section{$5.1 \quad$ SITE-SPECIFIC ISSUES}

Because ground water monitoring is not proposed at the Cheney disposal site, the only monitoring will be visual inspections of surface conditions during routine surveillance and maintenance. Previously unnoticed seeps or other surface exposures of ground water observed during routine site surveillance shall be noted and appropriate water samples shall be collected and analyzed to determine if the water is contaminated. If the analyses indicate the water is contaminated, the source of the water and the potential threat to human health and the environment will be assessed. If appropriate and necessary, the DOE may perform corrective actions to contain the source of the contaminated water and/or limit exposure of the land surface to the water. Such corrective actions may include, but are not limited to 1) constructing a sump or other device to collect the contaminated ground water before it reaches land surface, and treating or evaporating the water as necessary; or 2) controlling access to the contaminated water by covering it with graded, large-diameter rock until it can reinfiltrate or evaporate. The DOE has determined that the probability that surface exposure of tailings seepage is nearly zero; therefore, the necessity for corrective action at the Cheney disposal site is highly improbable.

\subsection{CORRECTIVE ACTION}

Corrective action is repairs that are needed to address problems that affect the integrity of the disposal cell or compliance with 40 CFR Part 192. The NRC must approve the recommended action in advance. Site inspections are designed to identify problems at the developmental stage. Examples of conditions that might trigger corrective action are as follows:

- Surface rupture or subsidence of the disposal cell.

- Development of rills, gullies, or slope instability on the disposal cell.

- Deterioration of the erosion-protection rock on the disposal cell.

- Tailings fluids originating from the disposal cell.

- Gully development on or immediately adjacent to disposal site property that could affect the integrity of the disposal cell.

- Damage to the cell cover or disposal site property from natural catastrophic events or vandalism.

- Damage to the disposal cell cover from deep-rooted plant growth. 
The DOE will evaluate the factors that caused the problem and identify actions to mitigate the impact and prevent recurrence. An onsite inspection or preliminary assessment will include but is not limited to:

- Identifying the nature and extent of the problem.

- Reevaluating germane engineering design parameters.

For conditions that warrant a follow-up inspection, the DOE will submit a preliminary assessment or status report to the NRC within 60 days of the inspection. The preliminary assessment report will evaluate the problem and recommend the next step (e.g., immediate action or continued evaluation). If the problem requires immediate repair, the DOE will develop a corrective action plan for NRC approval. Once the NRC approves the corrective action, the DOE will implement the plan. In some cases, corrective action could include temporary emergency measures instituted prior to completion of the normal approval process. If the problem does not require immediate repair, the problem will be documented in the annual report and assessed at the next annual inspection.

NRC regulations do not stipulate a time frame for implementing corrective action lexcept the finding of an exceedance in established ground water concentration limits, which does not apply at this site.) Assessing the extent of a problem and developing a corrective action plan is not considered to be an initiation of the corrective action program.

In addition to the preliminary assessment report, the DOE may, (as appropriate) prepare a progress report on each corrective action while it is under way or under evaluation.

After corrective action is complete, the DOE will certify work and submit a certification statement and supporting documentation to the NRC for review and concurrence. A copy of the certification statement will become part of the permanent site file, as will reports, data, and documentation generated during the corrective action. 


\subsection{RECORD KEEPING AND REPORTING}

\subsection{PERMANENT SITE FILE}

The DOE will maintain a permanent site file containing site inspection reports and other supporting documentation of long-term surveillance program activities. The information placed in the site file will include:

- Documentation of disposal site performance.

- Demonstration that licensing provisions were met.

- Information needed to forecast future site-surveillance and monitoring needs.

- Reports to stakeholders regarding disposal cell integrity.

After the site is brought under the general license, the DOE will compile copies of site documentation required by the long-term surveillance program guidance document (DOE, 1996a) for the Grand Junction Cheney disposal site permanent site file. Copies of deeds, custody agreements, and other property documents will be kept in the site file. The DOE will maintain surveillance and maintenance documentation identified in other sections of this LTSP and it will become part of the permanent site file. The DOE will update the site file as necessary after disposal site inspections, maintenance activities, or corrective actions are complete. These records will be handled in accordance with DOE directives to ensure their proper handling, maintenance, and disposition. The archival procedures set forth in 41 CFR Part 101 and 36 CFR Parts 1220-1238 (Subchapter B) will be followed. All information will be available for NRC and public review.

\subsection{INSPECTION REPORTS/ANNUAL REPORTS}

During site inspections, activities and observations will be recorded and described using site-inspection checklists, maps, photographs and photo logs, and field notes. Documentary evidence of anomalous, new, or unexpected conditions or situations must describe developing trends and enable the DOE to make decisions concerning follow-up inspections, custodial maintenance, and corrective action. This information will be contained in the permanent site file at the DOE office. The DOE will prepare a site inspection report documenting the findings and recommendations from field inspections.

Site inspection reports will be submitted to the NRC within 90 days of the annual site inspection. Inspection reports will summarize the results of follow-up inspections and maintenance completed since the previous annual inspection.

If unusual damage or disruption is discovered at the Cheney disposal site during an inspection, a preliminary report assessing the impact must be submitted to the NRC within 60 days. If maintenance, repair, or corrective action is warranted, the DOE will notify the NRC. The NRC will receive a copy of 
corrective action plans and of each corrective action progress report, or the reports will be attached to the annual report.

The DOE also will provide copies of inspection reports and other reports generated under the long-term surveillance program to the state of Colorado as required in the cooperative agreement. 
DOE (U.S. Department of Energy), 1997. Final Completion Report, Grand Junction, Colorado Disposal Site, Contract No. DE-AC04-83AL18796, prepared for the U.S. Department of Energy by MK-Ferguson Company, Albuquerque, New Mexico.

DOE (U.S. Department of Energy), 1996a. Guidance for Implementing the Long-Term Surveillance Program for UMTRA Project Title / Disposal Sites, DOE/AL-62350-189, Rev. O, prepared for the U.S. Department of Energy, Environmental Restoration Division, UMTRA Project Team, Albuquerque, New Mexico.

DOE (U.S. Department of Energy), 1996b. Long-Term Surveillance and Maintenance Program, Quality Assurance Program Plan, MAC-2152, Rev. 0, prepared by MACTEC Environmental Restoration Services, for the U.S. Department of Energy, Grand Junction Office, Grand Junction, Colorado.

DOE (U.S. Department of Energy), 1992. Vegetation Growth Patterns on Six Rock-Covered UMTRA Project Disposal Cells, UMTRA-DOE/AL 400677.0000, UMTRA Project Office, Albuquerque Operations Office, Albuquerque, New Mexico.

DOE (Department of Energy), 1991a. Remedial Action Plan and Site Design for Stabilization of the Inactive Uranium Mill Tailings Site at Grand Junction, Colorado, September 1991, DOE/AL-050505.0000, prepared for the U.S. Department of Energy, UMTRA Project Office, Albuquerque Operations Office, Albuquerque, New Mexico, Grand Junction Projects Office, UPDCC File Location No. 13.1.1.

DOE IU.S. Department of Energy, 1991b. Uranium Mill Tailings Remedial Action Project (UMTRAP), Grand Junction, Colorado, GRJ-PH-11, Subcontract Documents, Final Design for Construction, prepared for the U.S. Department of Energy by MorrisonKnudsen Engineers, San Francisco, California.

DOE (Department of Energy), 1986. Final Environmental Impact Statement, Remedial Actions at the Former Climax Uranium Company, Uranium Mill Site, Grand Junction, Mesa County, Colorado, Vol. I, Text, Vol. II, Appendices, DOE/EIS-0126-F, December 1986, UPDCC File Location No. 5.13.1.6., prepared for the U.S. Department of Energy, UMTRA Project Office, Albuquerque Operations Office, Albuquerque, New Mexico.

TAC (Technical Assistance Contractor), 1995. Unpublished field notes, Grand Junction Colorado, UMTRA Project site, 19-20 September 1995, UPDCC File Location No. 5.15.1.1, prepared by the Technical Assistance Contractor, Albuquerque, New Mexico, for the U.S. Department of Energy, Environmental Restoration Division, UMTRA Project Team, Albuquerque, New Mexico. 
10 CFR Part 40, Domestic Licensing of Source Material, U.S. Nuclear Regulatory Commission.

36 CFR Parts 1220-1238, National Archives and Records, Subchapter B - Records Management, National Archives and Records Administration.

40 CFR Part 143, National Secondary Drinking Water Regulations, U.S. Environmental Protection Agency.

40 CFR Part 192, Health and Environmental Protection Standards for Uranium and Thorium Mill Tailings, U.S. Environmental Protection Agency.

41 CFR Part 101, Federal Property Management Regulations, General Services Administration.

\section{DOE ORDERS}

Order 5700.6C, Quality Assurance, 21 August 1991, U.S. Department of Energy, Washington, D.C. 


\section{ATTACHMENT 1}

NRC CONCURRENCE AND LICENSING DOCUMENTATION

(To be provided when received) 
ATTACHMENT 2

SITE REAL ESTATE INFORMATION 


\section{GENERAL}

The disposal site is located on public land formerly administered by the U.S. Department of the Interior's (DOI) Bureau of Land Management (BLM). Under the requirements of the Uranium Mill Tailings Radiation Control Act (UMTRCA) of 1978, as amended, the U.S. Department of Energy (DOE) acquired the disposal site land via a Public Land Order (PLO) (42 USC $\$ 7901$ et seq.). The PLO permanently transferred 360 acres (146 hectares) from the public domain to the DOE in accordance with the terms of the UMTRCA. As a result of the transfer, the land is no longer subject to the general land laws, including mining and mineral leasing. The transfer of the land to the DOE vested in the DOE the full management, jurisdiction, and liability for the land and all activities conducted thereon, except that the BLM retained the authority to administer any claims or interests in the land established before the effective date of the transfer.

\section{LEGAL DESCRIPTION}

A tract of land located in Township 3 North Range 2 East, Ute Principal Meridian, described by the following government land survey. Section 11: SE1/4 SW1/4, S1/2 SE1/4; Section 14: NE1/4, E1/2 NW1/4. The area described contains approximately 360 acres of public land in Mesa County, Colorado.

\section{RECORDED}

The PLO was published in the Federal Register, dated 13 February 1990. The Federal Register document is listed as 90-3302, filed 12 February 1990 as 43 CFR Public Land Order 6767. The effective date of the transfer is 13 February 1990.

\section{REAL ESTATE FILES}

The U.S. Department of Energy maintains its real estate correspondence and related documents at the Albuquerque Operations Office, Property Management Branch, Property and Administrative Services Division, P.O. Box 5400, Albuquerque, New Mexico 87115, under the supervision of the Branch Chief, 505-845-6450.

\section{REFERENCE}

42 USC $\$ 7901$ et seq., Uranium Mill Tailings Radiation Control Act, 8 November 1978. 
55 FR 5012-01

RULES and REGULATIONS

\author{
DEPARTMENT OF THE INTERIOR \\ 43 CFR PUBLIC 3Land 30rder3 6767 \\ [C0-930-00-4214-10; $(C-39289)]$
}

Transfer of PUBLIC LAND for Cheney Reservoir Disposal site, Colorado Tuesday, February 13, 1990

AGENCY: Bureau of LAND Management, Interior.

ACTION: PUBLIC LAND ORDER.

SUMMARY: This ORDER permanently transfers 360 acres of PUBLIC LAND to the Department of Energy in accordance with the terms of the Uranium Mill Tailings Remedial Action Amendments Act of 1988.

EFFECTIVE DATE: February 13, 1990.

FOR FURTHER INFORMATION CONTACT: Doris E. Chelius, BLM Colorado state office, 2850 Youngfield Street, Lakewood, Colorado 80215-7076, 303-236-1752.

By virtue of the authority vested in the secretary of the Interior by sectid

106 of the Uranium Mill Tailings Radiation Control Act of 1978 (42 U.S.C. 7916), as amended by the Uranium Mill Tailings Remedial Action Amendments Act of 1988, Pub. L. 100-616, it is ordered as follows:

1. Subject to valid existing rights, the following described PUBLIC LAND is hereby permanently transferred to the Department of Energy and, as a result

this transfer, the LAND is no longer subject to the operation of the general LAND laws, including the mining and mineral leasing laws, for the cheney Reservoir Disposal Site:

Ute Principal Meridian

T. 3. S., R. 2 E.,

Sec. 11, SE $1 / 4$ SW $1 / 4, \mathrm{~S} 1 / 2$ SE $1 / 4$;

Sec. $14, \mathrm{NE} 1 / 4, \mathrm{E} 1 / 2 \mathrm{NW} 1 / 4$.

The area described aggregates 360 of PUBLIC LAND in Mesa County.

2. The transfer of the above-described LAND to the Department of Energy vest

in that Department the full management jurisdiction, responsibility, and liability for such LAND and all activities conducted thereon, except as provided in paragraph 3.

3. The secretary of the Interior shall retain the authority to administer an existing claims, rights, and interests in this LAND established before th 
tive date of the transfer.

ed: February 7, 1990.

o'Neal,

stant Secretary of the Interior.

Doc. 90-3302 Filed 2-12-90; 8:45 am] 
ATTACHMENT 3

EMERGENCY NOTIFICATION LETTERS 
湢

Director

(303) $236-1510$

Research

B031 236-1506
National Earthquake Information Center

World Data Center A for Seismology

C.S. Geological Survey

Box 25046, DFC. MS-96T

Degrer. Colorado 80205 LSA

Telex: (KTTCO) s106011123ESL LD
Operations

(303) 236-1500

QED

(800) 358.2663

Clinton C. Smythe

Engineering and Construction Group Leader

Uranium Mill Tailings Remedial Action

Project Office

2155 Louisiana NE, Suite 4,000

Albuquerque, NM 87110

Dear Mr. Smythe:

This letter is to confirm that the DOE Grand Junction Projects Office (24-hour phone line, (303) 248-6070 has been added to our notification list for the occurrence of earthquakes near the following locations:

\begin{tabular}{|c|c|c|}
\hline Disposal Site & Latitude & Longitude \\
\hline COLORADO & & \\
\hline Durango (Bodo Canyon) & N37.15 & W107.90 \\
\hline Grand Junction & N38.91 & W108.32 \\
\hline Gunnison (Landfill) & N38.51 & W106.85 \\
\hline Maybell & N40.55 & W107.99 \\
\hline Naturita (Dry Flats) & N38.21 & W108.60 \\
\hline Rifle (Estes Gulch) & N39.60 & W107.82 \\
\hline Slick Rock (Burro Canyon) & N38.05 & W108.87 \\
\hline IDAHO & & \\
\hline Lowman & N44.16 & W115.61 \\
\hline NEW MEXICO & & \\
\hline Ambrosia Lake & N35.41 & W107.80 \\
\hline NORTHDAKOTA & & \\
\hline Bowman & N46.23 & W103.55 \\
\hline OREGON & & \\
\hline Lakeview (Collins Ranch) & N42.2 & W120.3 \\
\hline PENNSYIVANIA & & \\
\hline Canonsburg & N40.26 & W80.25 \\
\hline BuTrell VP & N40.62 & W79.65 \\
\hline TEXAS & & \\
\hline Falls City & N28.91 & W98.13 \\
\hline UTAH & & \\
\hline Mexican Hat & N37.10 & W109.85 \\
\hline Salt Lake City (Clive) & N40.69 & W113.11 \\
\hline
\end{tabular}


National Earthquake Information Center. World Data Center A for Seismology

Director (c03) 236-1510

Research (303) 236-1506
U.S. Geologies Survey

Box 25046, DFC, MS 967

Denver, Colorado 80225 USA

Telex: (WTTCO) 5106014123 ESL ID
Operations

(303) 236-1500

QED

(800) 358-2663

Clinton C. Smythe

$-2-$

We have entered the following selection criteria into our notification program:

1. Any earthquake of magnitude 3.0 or greater, within 0.3 degrees (about 20 miles) of any site shown above, or

2. Any earthquake of magnitude 5.0 or greater, within 1.0 degrees (about 70 miles) of any site shown above. .

Sincerely,

Duce w. Present

Brice Presgrave

U.S. Geological Survey

National Earthquake Information Center

P.O. Box 25046

Mail Stop 967

Denver Federal Center

Denver, Colorado 80225

Please address future comespondonce to Stuart Koyanagi at the above address. I have moved to a different project.

Thank you + best regards,.

Dunce Prugrave

A3-2 